\title{
Dietary Surveys: Variation in the Weekly Intake of Nutrients
}

\author{
BY JOHN YUDKIN \\ King's College of Household and Social Science, \\ University of London
}

(Received 22 September 1950)

Much effort has been expended in recent years in assessing the adequacy of diets by measuring food consumption. The principle is to determine the intake of nutrients and to compare this with standards of requirements: an intake lower than the requirement is then taken to indicate an inadequate diet. The limitations in the use of these standards have been discussed elsewhere (Yudkin, 1948). The present paper deals with some of the limitations in the methods of determining dietary intakes, and more particularly with the week-to-week variation in intakes.

The practical difficulties involved have led to the adoption of many different methods, which vary greatly in complexity. In many circumstances, it is quite impossible to use the more complex methods, so that the simpler methods are used perforce and accuracy is sacrificed to expediency. The extent of the errors likely to be introduced has recently been the subject of investigation, so that the limitations of the various methods are now becoming known (see, for example, Bransby, Daubney \& King, 1948a, $b$ ).

Whatever method is chosen, it remains necessary to decide for how long the measurement of intake should be made. Because of the laborious nature of even the simpler methods of conducting surveys, this question resolves itself in practice into deciding the minimal time which reasonably reflects the normal pattern of food consumption. It is recognized that the amounts of different foods consumed vary from day to day and that, in most western dietaries, this variation may be quite large (cf. Wait \& Roberts, 1932; McKay \& Patton, 1935). Most workers agree that, in western countries, it is necessary to measure the intake for a week. More important, they also agree that such a period is sufficient to give a reasonably accurate assessment of the amounts and sorts of foods habitually consumed by individuals (cf. Food and Agriculture Organization of the United Nations, 1949). But there is relatively little published on this point. Widdowson \& McCance (1945) and Widdowson (1947) studied the diets of 'a number of children' for periods of 4 consecutive weeks. From these results and from similar results of Boulton (1945), Widdowson (1947, p. 73) concludes that, at least for calories, a week's study gives a fair assessment of a person's intake. On the other hand, McHenry, Ferguson \& Gurland (1945) reported great variation in weekly intakes measured for the rst week of each month for a year. Their results led them to decide that 'dietary surveys for a period of one week should not be used to ascertain the extent of deficiencies in persons having ... a free-will choice of foods'.

Further data on the adequacy of weekly studies of intake are clearly desirable, and this paper reports an investigation designed to provide them. 


\section{EXPERIMENTAL}

Details of subjects. It is usual for the postgraduate dietetic students at this College to determine their own dietary intakes for I week. During the session 1948-9, the five students of that year and one of the members of the staff were asked to keep records of their dietary intakes for 4 consecutive weeks. Two of the students measured their intakes for a further week after a short interval. All of the subjects were women. One of them (subject no. 6) was in the 5th month of her first pregnancy. Table I shows the periods during which the food consumption was measured and also gives some personal data of the subjects. None of them had any illnesses during these periods; it might also be stated at once that there was no obvious relationship between food consumption and menstruation.

\begin{tabular}{|c|c|c|c|c|}
\hline $\begin{array}{c}\text { Subject } \\
\text { no. }\end{array}$ & Period of study & $\begin{array}{c}\text { Age } \\
\text { (years) }\end{array}$ & $\begin{array}{l}\text { Weight } \\
\text { (lb.) }\end{array}$ & $\begin{array}{l}\text { Height } \\
\text { (in.) }\end{array}$ \\
\hline I & $\begin{array}{l}15 \text { Nov.-12 Dec. } 1948 \\
\text { 30 Jan.-5 Feb. } 1949\end{array}$ & 21 & r31 & 63 \\
\hline 2 & $\begin{array}{l}\text { I4 Nov.-1 I Dec. I948 } \\
\text { 30 Jan.-5 Feb. I949 }\end{array}$ & 20 & 121 & 67 \\
\hline 3 & 16 Nov.-13 Dec. 1948 & 21 & 146 & 70 \\
\hline 4 & 17 Nov. -14 Dec. 1948 & 20 & 159 & 663 \\
\hline 5 & 17 Nov. -14 Dec. 1948 & 26 & 108 & $6 \times 1$ \\
\hline 6 & 21 Apr.-19 May 1949 & 34 & 160 & $67 \frac{1}{2}$ \\
\hline
\end{tabular}

Food consumed and calculation of nutrients. All of the subjects ate 'elevenses', lunch and tea at the College from Monday to Friday, and the remaining meals at their homes or lodgings or a students' hostel. It was thus possible to ascertain the composition of most made-up dishes and calculate the amounts of nutrients therein from the ingredients. The food consumed was weighed by each subject herself.

Three of the subjects took daily supplementary amounts of nutrients as follows. Subject no. 2: vitamin A 500 i.u., vitamin D 1400 i.u., calcium $325 \mathrm{mg}$. Subject no. 3 : vitamin A 4500 i.u., vitamin $B_{1} 0.15 \mathrm{mg}$, riboflavin $0.05 \mathrm{mg}$., vitamin C $10 \mathrm{mg}$., vitamin D 600 i.u. Subject no. 6: vitamin A 4000 i.u., vitamin D 800 i.u., calcium $750 \mathrm{mg}$.

The nutrients in the diets were calculated by reference to food tables. Almost all the values were taken from 'Nutritive Values of War-time Foods' (Accessory Food Factors Committee, 1945), with some additional and revised values kindly supplied by the Ministry of Food. Occasionally, it was necessary to refer to the tables prepared by Platt (1945).

Since it is now agreed-and was readily confirmed in this study-that the intake varies greatly from day to day, and since the purpose of this work was to determine the weekly variation in intake, all the results have been calculated as the average daily intake for each week. These averages, and the average for the whole 4-weekly period, are given graphically for calories and for each nutrient; where appropriate, the graphs 
also indicate the recommended allowances suggested by the British Medical Association (1950) and by the (U.S.A.) National Research Council (1948). These will be referred to as the allowances of the B.M.A. and N.R.C.

Since subject no. 6 was about half-way through her pregnancy during the measurement of her intake, her allowances have been taken as the mean of those for the first half and for the second half of pregnancy.

In order to give a truer picture of the nutrients contained in the diets as consumed, the supplementary nutrients, taken by subjects nos. 2, 3 and 6, have not been included in the results given nor considered in the discussion thereon.

\section{RESULTS}

Variation in weekly intake

The variations in intake between subjects, and the variations from week to week in the same subjects, are given in Figs. 1-4. It will be seen that the extent of the weekly variation differs from subject to subject and also from nutrient to nutrient. It is least with calories, where the difference between the highest and lowest intake of an individual is from 2 to $68 \%$; it is most with vitamin $\mathrm{D}$, where the difference is from $25^{\circ}$ to $650 \%$.

Some special points about individual nutrients are worth noting.

Calories. The recommended allowances of calories for the five students have been taken as those for 'light work and travelling' (2250 Cal., B.M.A.) or for 'moderately active women' ( 2400 Cal., N.R.C.). Throughout the 4 weeks, the intake of calories by subject no. 5 was appreciably lower than the recommended allowances and those by subjects nos. 2 and 4 slightly lower.

The contributions made by protein, fat and carbohydrates to the total caloric intake are shown in Table 2.

Table 2. Calories supplied by protein, fat and carbohydrate in the diets of the six subjects averaged over 4 weeks

\begin{tabular}{cccc} 
Subject & \multicolumn{3}{c}{ Percentage of calories supplied from } \\
\cline { 2 - 4 } no. & Protein & Fat & Carbohydrate \\
1 & 14 & 39 & 47 \\
2 & 12 & 40 & 48 \\
3 & 14 & 37 & 49 \\
4 & 15 & 35 & 50 \\
5 & 17 & 40 & 43 \\
6 & 14 & 35 & 51
\end{tabular}

Protein. Since it is held that, for reasons concerned more with the presence of associated factors than with its content of essential amino-acids, protein from animal sources is nutritionally superior to protein from vegetable sources, a summary is given of the proportion of the total protein derived from animal foods (Table 3 ). In addition, a calculation has been made of the proportion of the calories supplied by the protein, since it has been suggested that an adequate intake of protein is one which in normal 
adults supplies I $\%$ of the calories or which, in pregnant women, supplies $14 \%$ of the calories (British Medical Association, 1950).

In four of the five students, the proportion supplied from animal foods was between

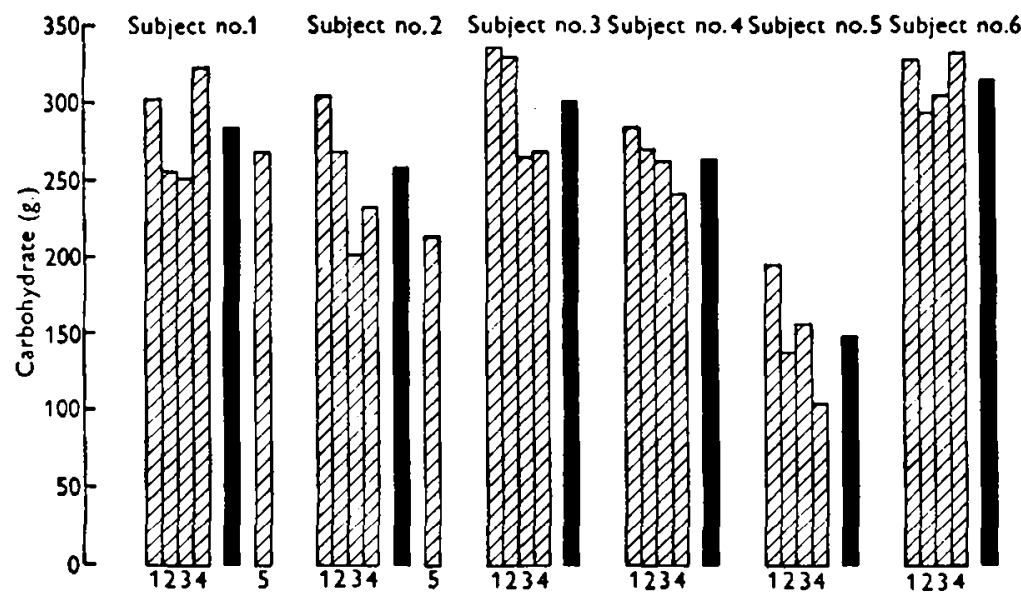

Fig. s. Variation in weekly intake of carbohydrate, fat, protein and calories of the six subjects. Hatched columns show average daily intake in each of the 4 (or 5) weeks of study. Solid column gives mean daily intake over 4 consecutive weeks. Dotted lines indicate recommended allowance of the (U.S.A.) National Research Council (1948) (N.R.C.) and British Medical Association (1950) (B.M.A.).

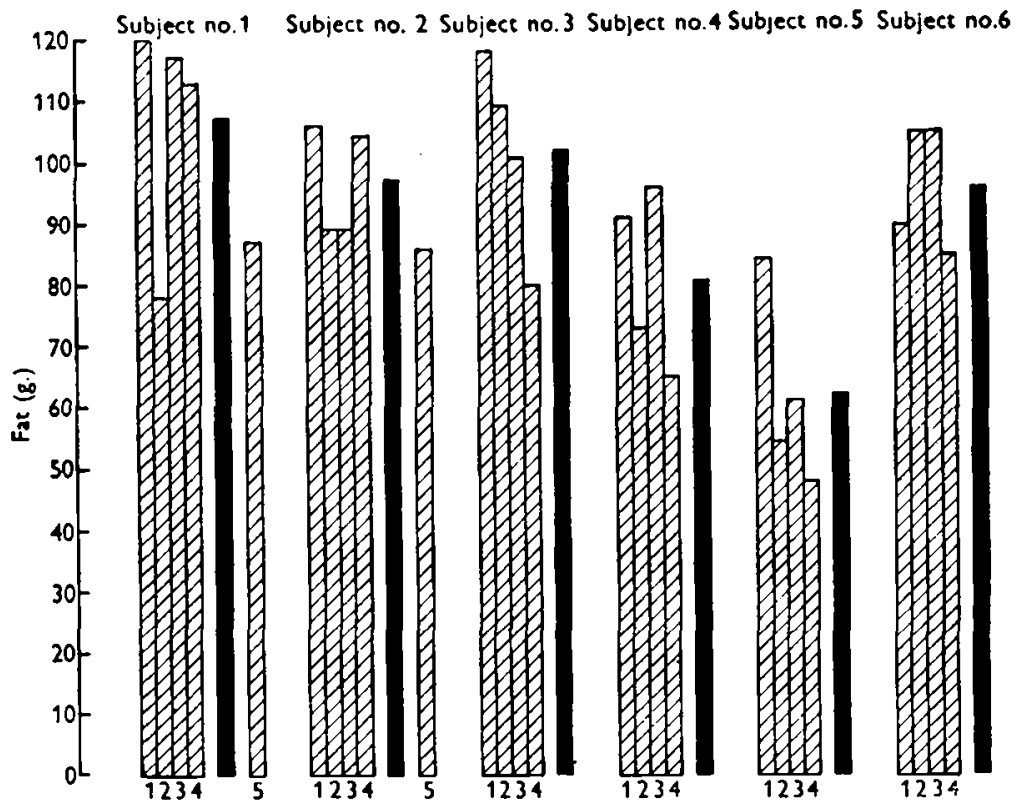

Fig. I (cont.)

52 and $56 \%$. The fifth took $70 \%$ of her protein in animal foods. Much of this came from milk; her average consumption of this for the 4 weeks was 0.381 . daily, whereas the other four students took an average of $0.10-0.251$. daily. The pregnant subject 


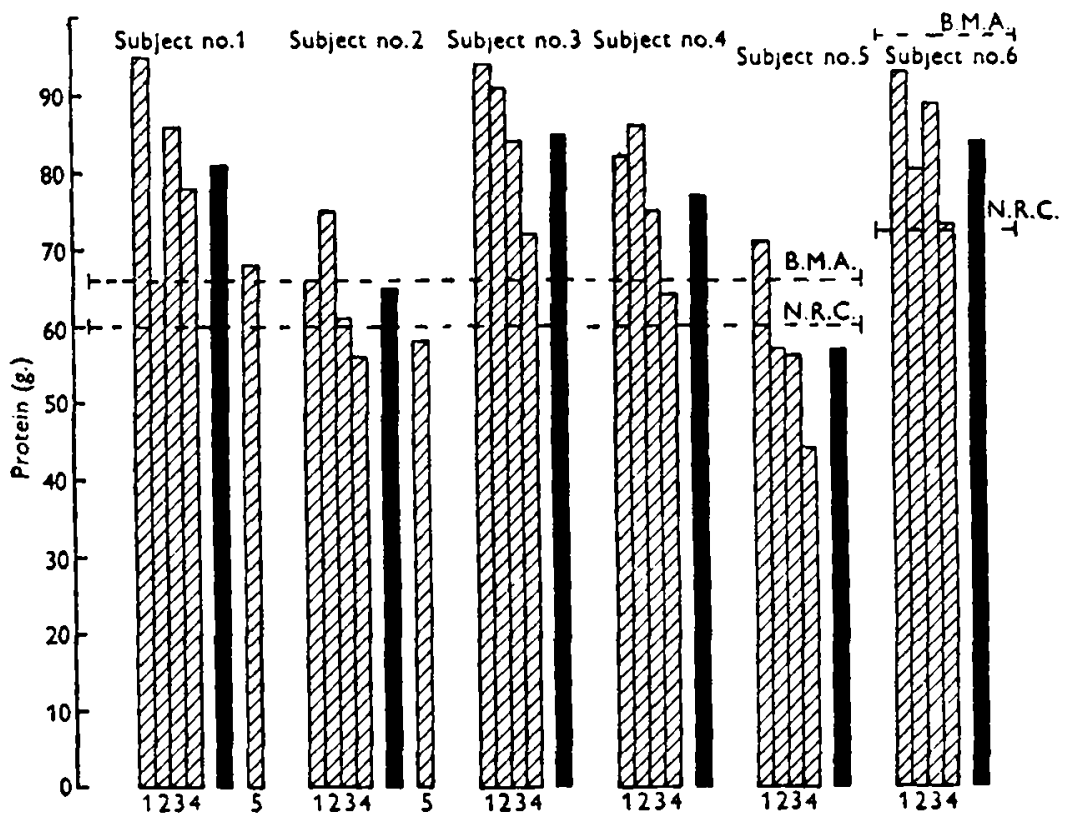

Fig. I cont.)

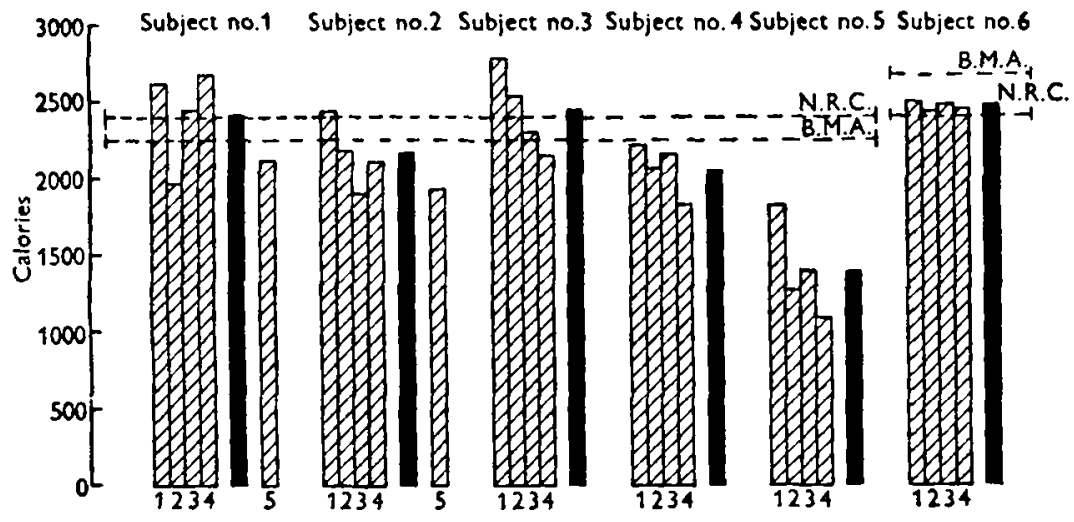

Fig. I (cont.)

Table 3. Average daily protein intake of the six subjects over 4 weeks, proportion of animal protein and proportion of calories supplied by protein

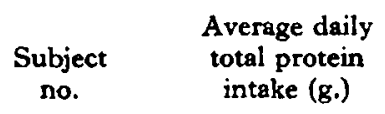

1
2
3
4
5
6

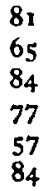

Percentage of total protein derived from animal foods
Percentage of total calories derived from protein

$\begin{array}{llr}81 & 53 & 13 \cdot 8 \\ 65 & 52 & 12 \cdot 3 \\ 84 & 56 & 14 \cdot 2 \\ 77 & 55 & 15 \cdot 3 \\ 57 & 70 & 16 \cdot 8 \\ 84 & 66 & 13 \cdot 9\end{array}$


no. 6 also had a high proportion of animal protein $(66 \%)$ in her diet; her milk consumption was higher than that of any other subject, 0.491 . daily. The proportion of calories supplied by protein was near enough to the suggested allowances of $14 \%$ for the pregnant subject; for the other subjects, it was well above the suggested II \% $(\mathrm{r} 2 \cdot 3-\mathrm{r} 6 \cdot 8 \%$ ).

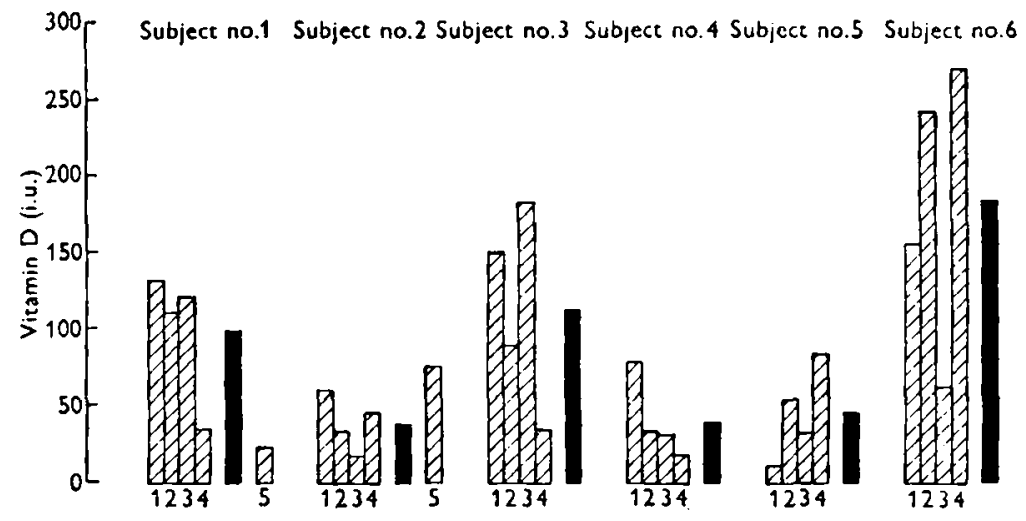

Fig. 2. Variation in weekly intake of vitamin $D$, vitamin $A$ and carotene, iron, and calcium of the six subjects. The contribution of carotene was calculated on the assumption that 3 i.u. carotene are equal to I i.u. preformed vitamin A. For further information see Fig. $x$.

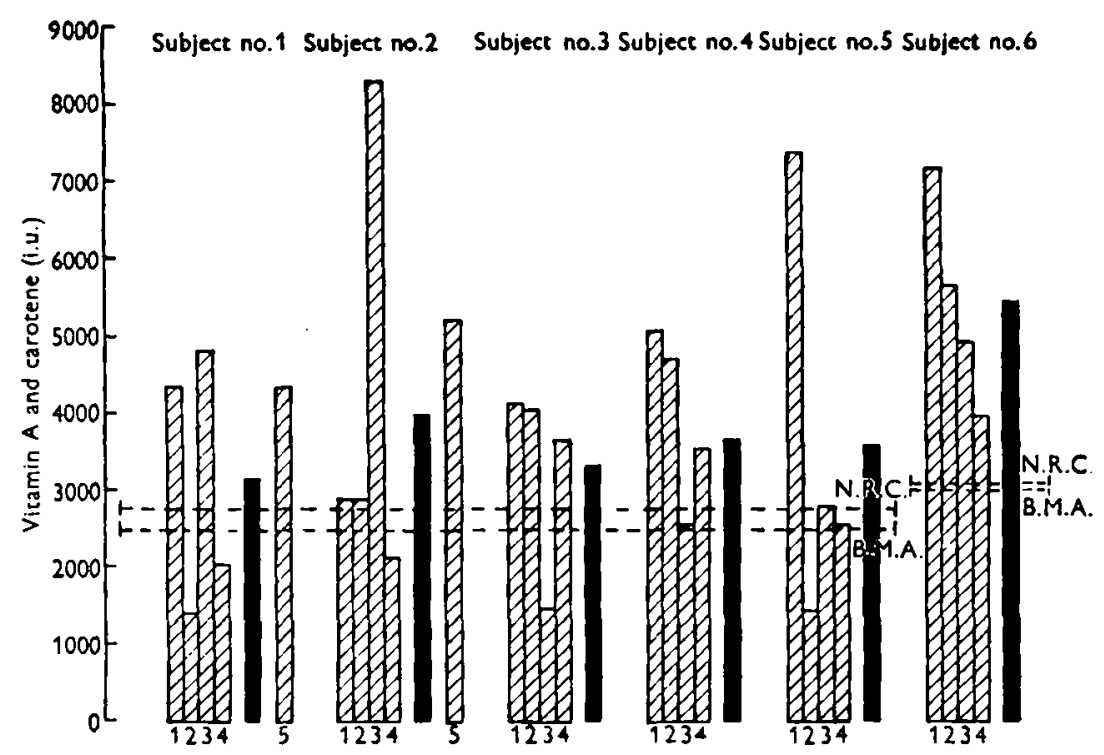

Fig. 2 (cont.)

Calcium. As with protein, the intake of calcium of subject no. 5, in spite of her low consumption of food in general, was as good as that of the other students because of her high intake of milk. Again, the highest intake of calcium was that of subject no. 6 whose diet contained the highest amounts of milk.

No allowance has been made for calcium supplied from tap water, which in London 
would increase the intake by about $0.1 \mathrm{~g}$. (Widdowson $\& \mathrm{McCance}, 1943$ ). This would bring the average 4 -weekly intake of the five students well above the B.M.A. standard but still below the N.R.C. standard.

Vitamin $A$. It is now known that there is appreciable variation in the vitamin A activity of carotene, depending both on the subject consuming it and on the food
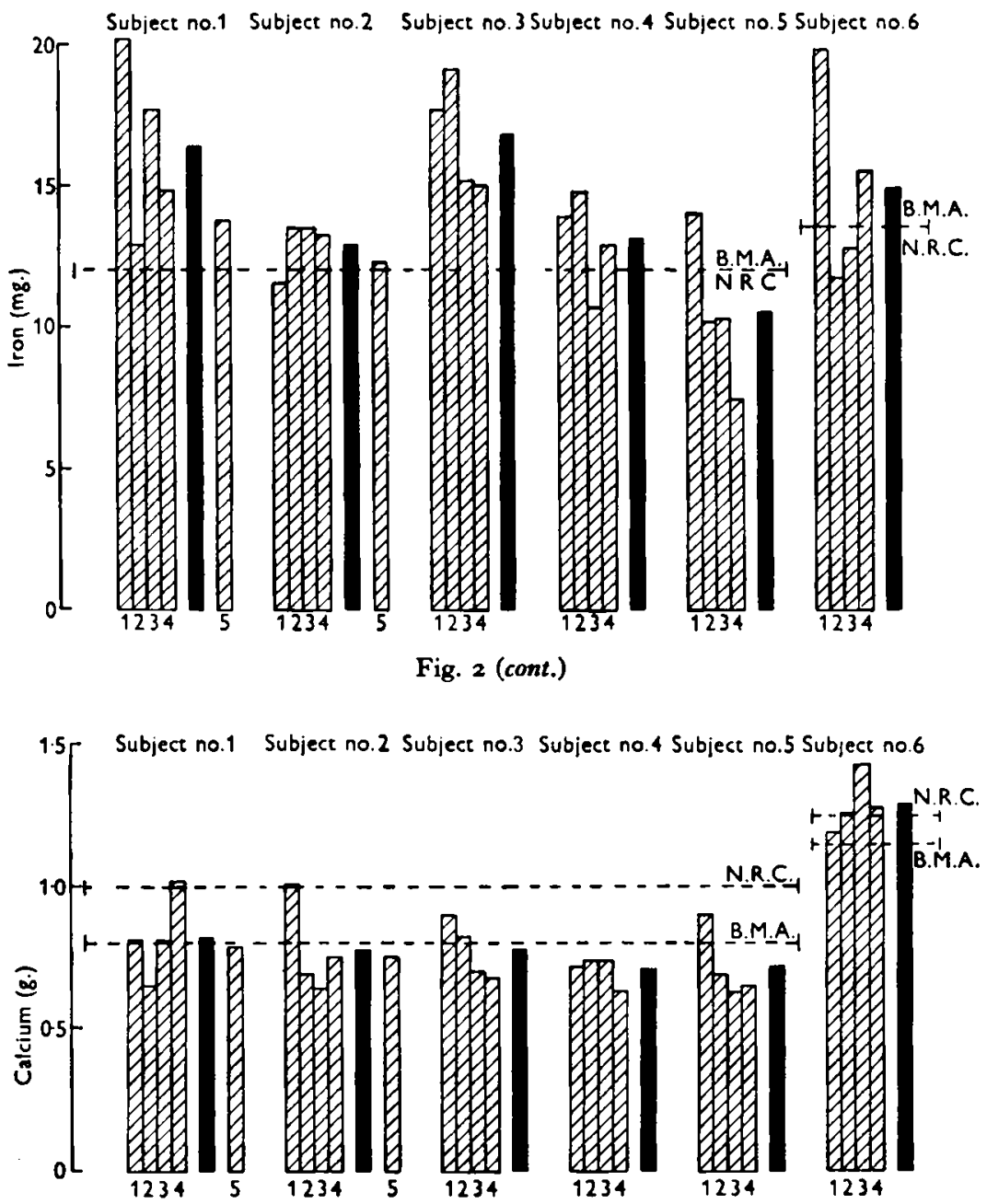

Fig. 2 (cont:)

from which it comes. A reasonable estimate, however, is given if it is assumed that 3 i.u. carotene are equal in potency to $x$ i.u. of preformed vitamin $A$. This assumption has been made in the calculations herein reported.

The chief sources of vitamin $A$ in the weeks of high consumption were liver and carrots. For example, one helping of $152 \mathrm{~g}$. liver in the $3^{\text {rd }}$ week gave subject no. 2 about 33,000 i.u. vitamin A, an average of about 4700 i.u. daily. Four helpings of 287 g. carrots in the 2nd week gave subject no. 4 about 60,000 i.u. carotene, equivalent 
to 20,000 i.u. vitamin $A$ in a week or an average of about 3000 i.u. vitamin A daily. Without these two rich sources of the preformed vitamin or of carotene, the intake would have varied much less from week to week (Table 4 ).

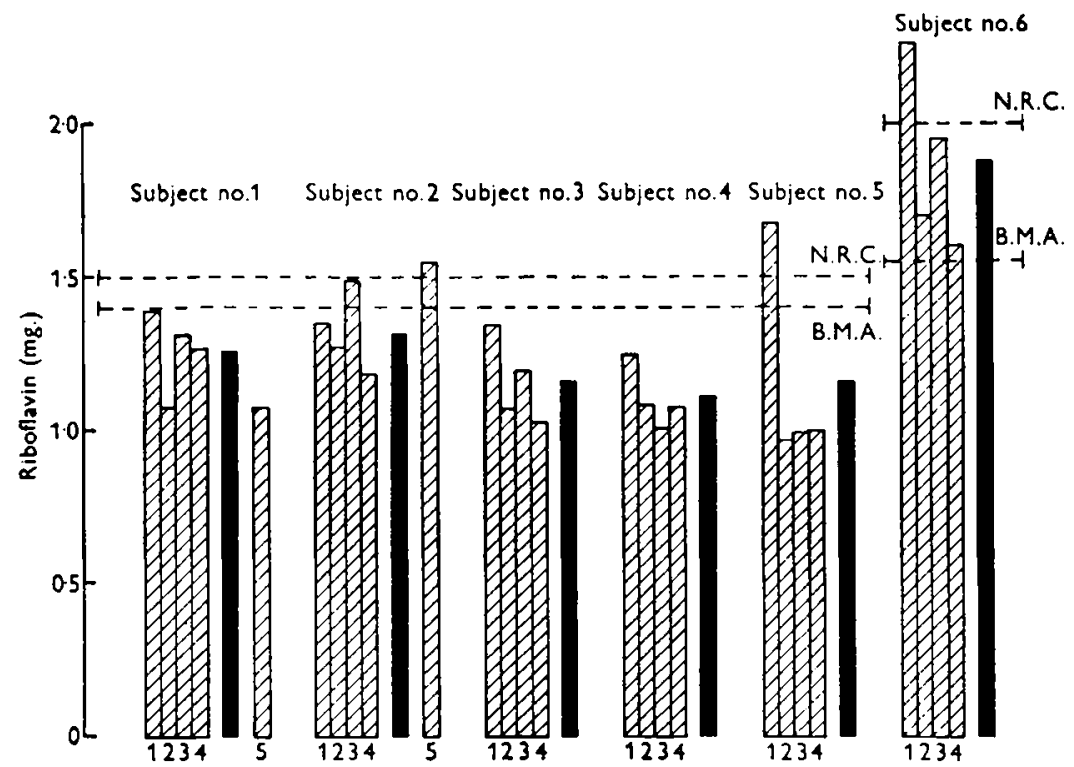

Fig. 3. Variation in weekly intake of riboflavin, nicotinic acid, vitamin $C$ and vitamin $B_{1}$ of the six subjects. For further information see Fig. I.

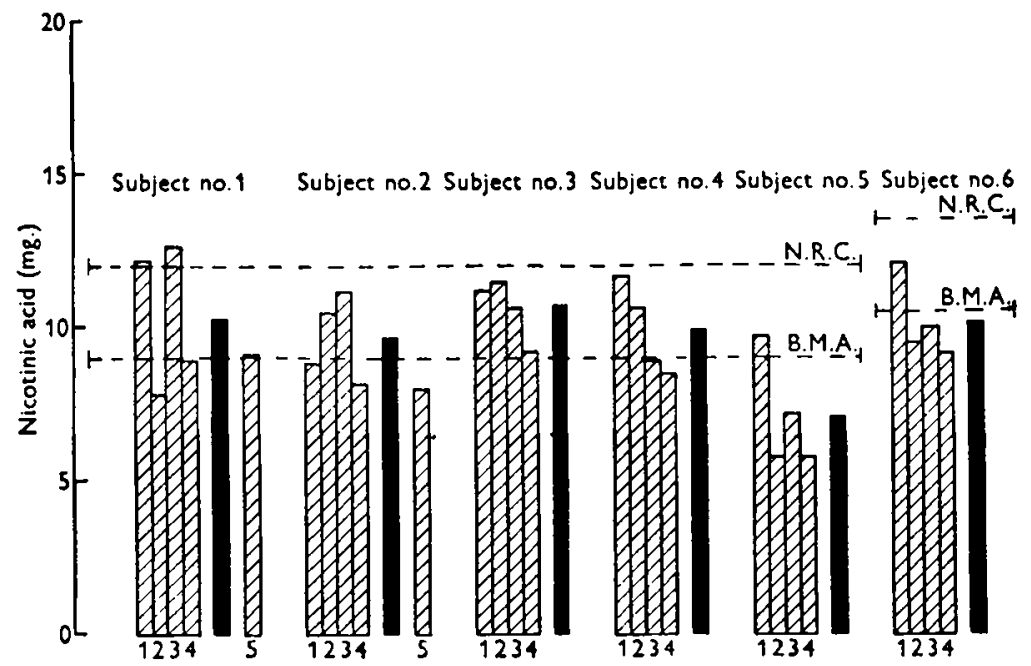

Fig. 3 (cont.)

The average mixed western diet is said to contain two-thirds of its vitamin $A$ as carotene. On the assumption that carotene has one-third the potency of the preformed vitamin, this would mean that it constitutes $40 \%$ of the total dietary vitamin A. The actual value varies from 30 to $50 \%$ (Table 5). 
Riboflavin. The average daily intake of subject no. $6,1.88 \mathrm{mg}$., was higher than that of any of the other subjects and, like her intake of calcium, was to a large extent,due

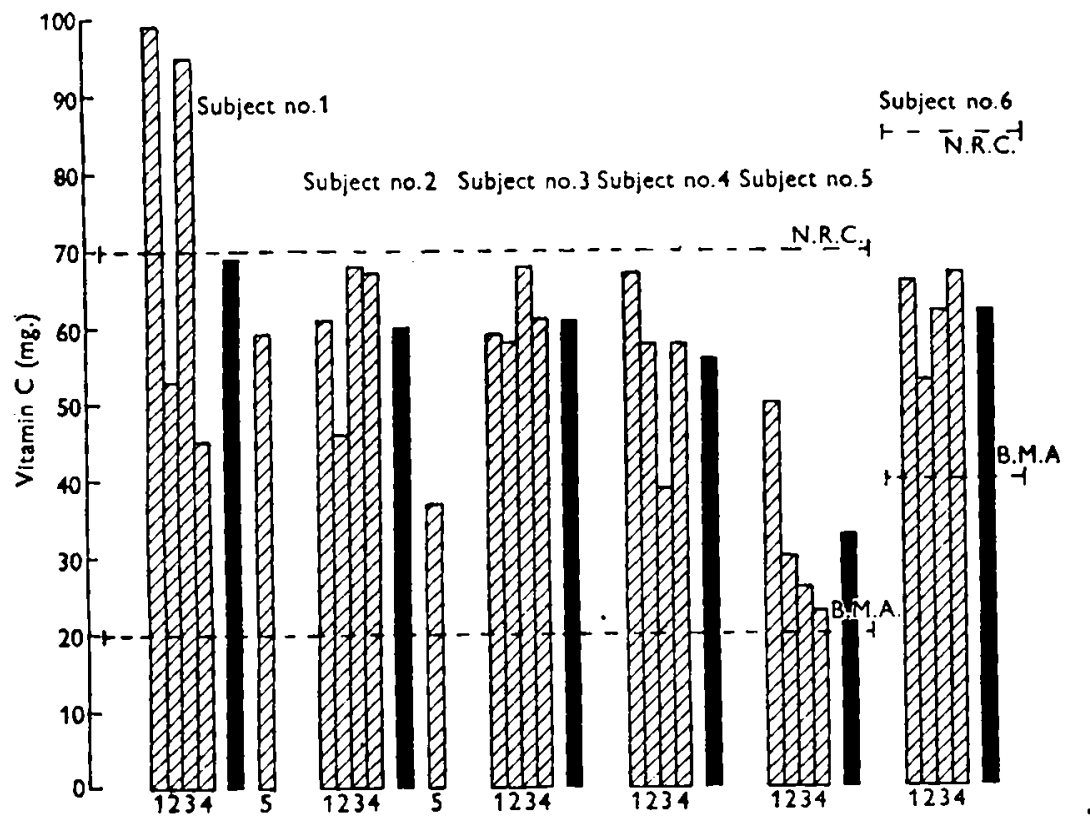

Fig. 3 (cont.)

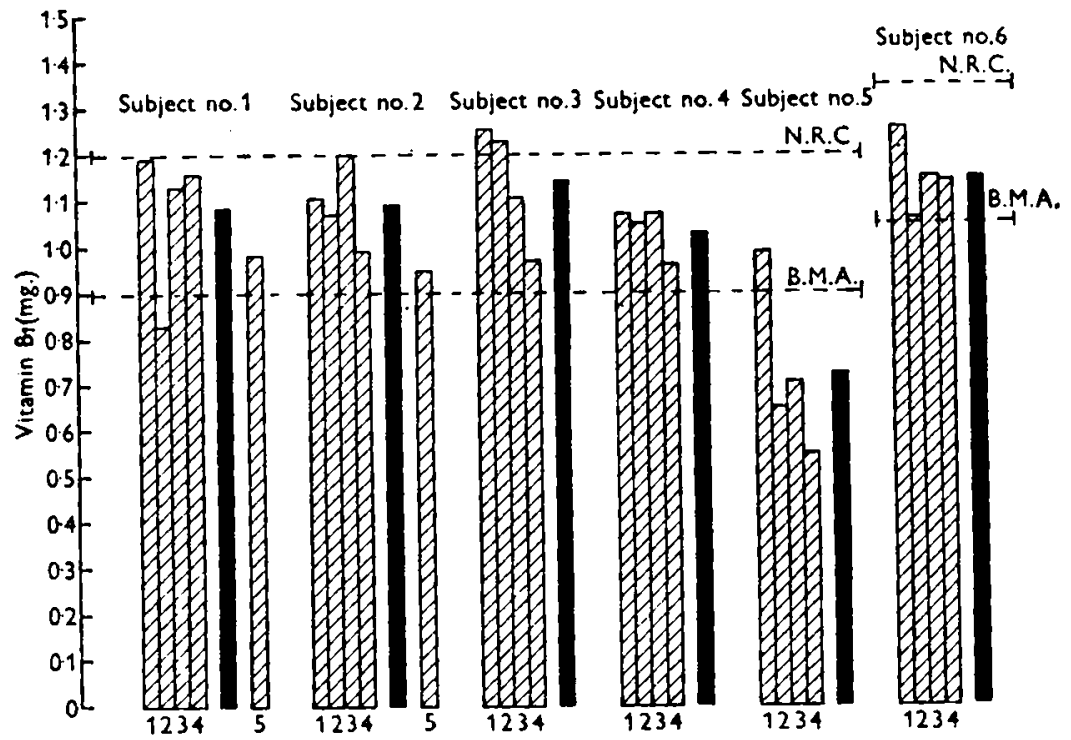

Fig. 3 (cont.)

to her high consumption of milk. This alone supplied an average of nearly I mg. of riboflavin daily.

Vitamin $C$. The values given for vitamin $\mathrm{C}$ allow for losses in cooking. Owing, 
however, to the great differences that may occur in such losses, due, for example, to differences in time of cooking, amount of water used, and the time for which vegetables may be kept on the hot plate, the values for vitamin $\mathrm{C}$ are likely to be less accurate
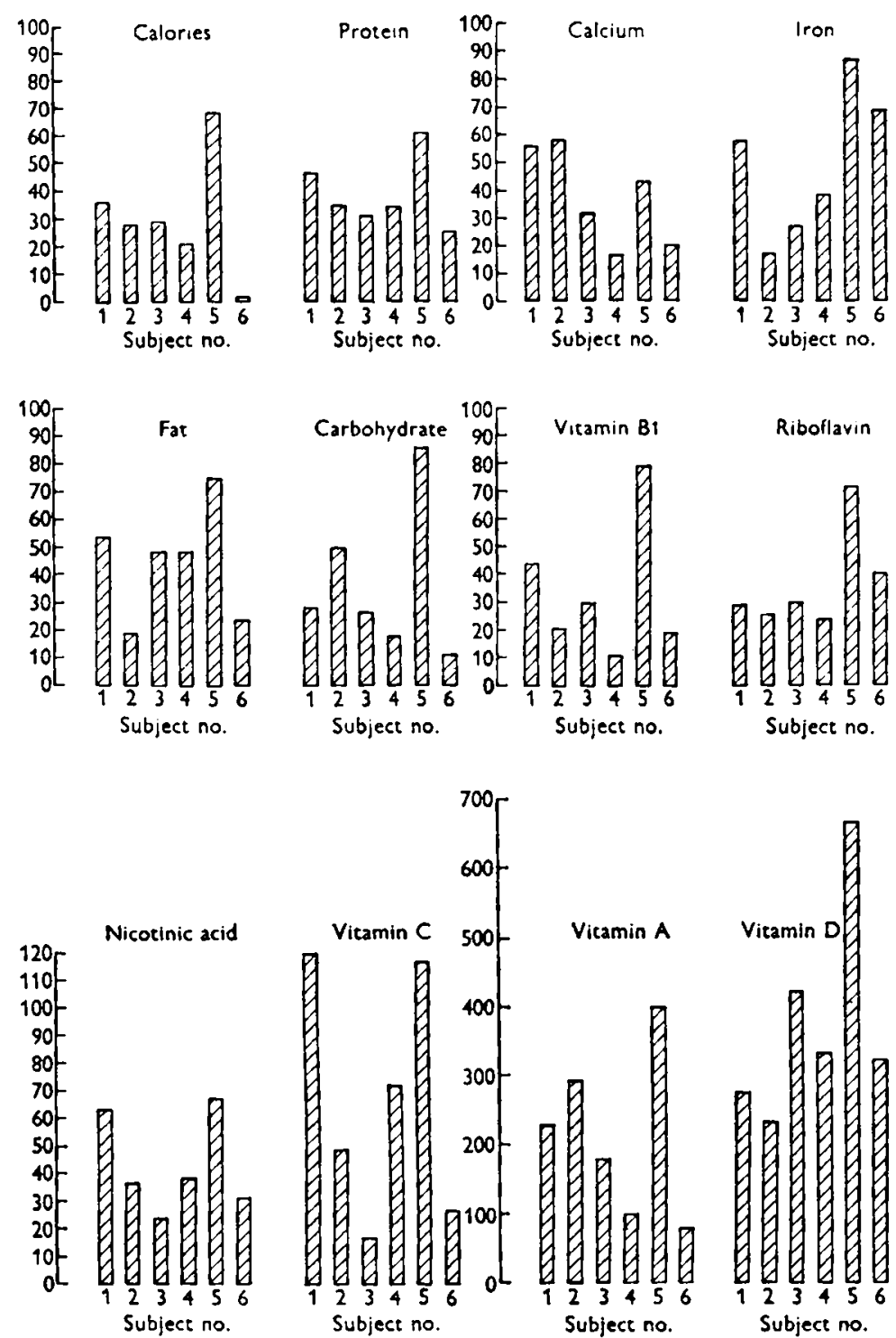

Fig. 4. Difference between highest and lowest weekly intakes of calories, protein, calcium, iron, fat, carbohydrate, vitamin $B_{1}$, riboflavin, nicotinic acid and vitamins $C, A$ and $D$ of the six subjects. Figures give difference as percentage of lowest intake.

than those for other nutrients. Nevertheless, the relative values in the different weekly measurements are probably reliable.

Vitamin $D$. The weekly variation with each subject is due, like that of vitamin $\mathbf{A}$, to the presence or absence in the weekly diet of a potent source of the vitamin. With 
Table 4. Average daily intake (i.u.) of vitamin A supplied by liver, carrots and other foods in the diets of the six subjects

\begin{tabular}{|c|c|}
\hline $\begin{array}{c}\text { Subject } \\
\text { no. }\end{array}$ & $\begin{array}{c}\text { Source of } \\
\text { vitamin A }\end{array}$ \\
\hline $\mathbf{I}$ & $\begin{array}{l}\text { Liver } \\
\text { Carrots } \\
\text { Other foods }\end{array}$ \\
\hline 2 & $\begin{array}{l}\text { Liver } \\
\text { Carrots } \\
\text { Other foods }\end{array}$ \\
\hline 3 & $\begin{array}{l}\text { Liver } \\
\text { Carrots } \\
\text { Other foods }\end{array}$ \\
\hline 4 & $\begin{array}{l}\text { Liver } \\
\text { Carrots } \\
\text { Other foods }\end{array}$ \\
\hline 5 & $\begin{array}{l}\text { Liver } \\
\text { Carrots } \\
\text { Other foods }\end{array}$ \\
\hline 6 & $\begin{array}{l}\text { Liver } \\
\text { Carrots } \\
\text { Other foods }\end{array}$ \\
\hline
\end{tabular}

\begin{tabular}{|c|c|c|c|c|}
\hline \multicolumn{5}{|c|}{ Week } \\
\hline $\mathbf{I}$ & 2 & 3 & 4 & 5 \\
\hline 1000 & 0 & 900 & 0 & 0 \\
\hline 1080 & 0 & 1000 & 0 & 3050 \\
\hline 2280 & 1470 & 2930 & 2040 & 1310 \\
\hline 0 & o & 4640 & 0 & 3010 \\
\hline 260 & 790 & 1000 & 0 & 0 \\
\hline 2640 & 2110 & 2680 & 2120 & 2190 \\
\hline 950 & 0 & 0 & 1250 & - \\
\hline 1240 & 1860 & 150 & 1320 & - \\
\hline 1950 & 2190 & $133^{\circ}$ & 1090 & - \\
\hline I 560 & 0 & 0 & 1460 & - \\
\hline 2170 & 2860 & 1040 & 520 & - \\
\hline 1360 & 1850 & 1510 & 1570 & . - \\
\hline 3290 & 0 & 0 & 780 & - \\
\hline 1860 & 110 & 910 & 350 & - \\
\hline 2230 & 1370 & I8́go & 1430 & - \\
\hline 4240 & 0 & 0 & 0 & - \\
\hline 510 & 2670 & 1810 & 0 & - \\
\hline 2420 & 2980 & 3130 & 3980 & - \\
\hline
\end{tabular}

- Calculated for carotene on the assumption that 3 i.u. carotene are equal to 1 i.u. preformed vitamin $\mathbf{A}$.

Table 5. Average daily intake (i.u.) of vitamin $A$ and carotene by the six subjects*

\begin{tabular}{|c|c|c|c|c|c|c|c|}
\hline \multirow[b]{2}{*}{$\begin{array}{c}\text { Subject } \\
\text { no. }\end{array}$} & \multicolumn{5}{|c|}{ Week } & \multirow[b]{2}{*}{$\begin{array}{l}\text { Mean of } \\
4 \text { weeks }\end{array}$} & \multirow[b]{2}{*}{ Week 5} \\
\hline & & I & 2 & 3 & 4 & & \\
\hline I & $\begin{array}{l}\text { Vitamin A } \\
\text { Carotene } \\
\text { Total }\end{array}$ & $\begin{array}{l}2120 \\
2240 \\
4360\end{array}$ & $\begin{array}{r}1020 \\
45^{\circ} \\
1470\end{array}$ & $\begin{array}{l}2740 \\
2090 \\
4830\end{array}$ & $\begin{array}{r}1540 \\
500 \\
2040\end{array}$ & $\begin{array}{l}1850 \\
1320 \\
3170\end{array}$ & $\begin{array}{r}980 \\
3380 \\
4360\end{array}$ \\
\hline 2 & $\begin{array}{l}\text { Vitamin A } \\
\text { Carotene } \\
\text { Total }\end{array}$ & $\begin{array}{l}1840 \\
1060 \\
2900\end{array}$ & $\begin{array}{l}1240 \\
1660 \\
2900\end{array}$ & $\begin{array}{l}6590 \\
1730 \\
8320\end{array}$ & $\begin{array}{r}1830 \\
290 \\
2120\end{array}$ & $\begin{array}{l}2770 \\
1200 \\
3970\end{array}$ & $\begin{array}{r}4880 \\
320 \\
5200\end{array}$ \\
\hline 3 & $\begin{array}{l}\text { Vitamin A } \\
\text { Carotene } \\
\text { Total }\end{array}$ & $\begin{array}{l}2390 \\
1750 \\
4140^{\circ}\end{array}$ & $\begin{array}{l}2000 \\
2050 \\
4050\end{array}$ & $\begin{array}{r}1140 \\
340 \\
1480\end{array}$ & $\begin{array}{l}2140 \\
1520 \\
3660\end{array}$ & $\begin{array}{l}1920 \\
1420 \\
3340\end{array}$ & $\begin{array}{l}- \\
-\end{array}$ \\
\hline 4 & $\begin{array}{l}\text { Vitamin A } \\
\text { Carotene } \\
\text { Total }\end{array}$ & $\begin{array}{l}2540 \\
2550 \\
5090\end{array}$ & $\begin{array}{l}1250 \\
3460 \\
4710\end{array}$ & $\begin{array}{r}890 \\
1660 \\
2550\end{array}$ & $\begin{array}{l}2470 \\
1080 \\
3550\end{array}$ & $\begin{array}{l}1820 \\
1840 \\
3660\end{array}$ & - \\
\hline 5 & $\begin{array}{l}\text { Vitamin A } \\
\text { Carotene } \\
\text { Total }\end{array}$ & $\begin{array}{l}4830 \\
2550 \\
7380\end{array}$ & $\begin{array}{r}1140 \\
340 \\
1480\end{array}$ & $\begin{array}{l}1280 \\
1520 \\
2800\end{array}$ & $\begin{array}{r}1920 \\
640 \\
2560\end{array}$ & $\begin{array}{l}2330 \\
1250 \\
35^{80}\end{array}$ & - \\
\hline 6 & $\begin{array}{l}\text { Vitamin A } \\
\text { Carotene } \\
\text { Total }\end{array}$ & $\begin{array}{r}6230 \\
940 \\
7170\end{array}$ & $\begin{array}{l}2460 \\
3190 \\
5650\end{array}$ & $\begin{array}{l}2030 \\
2910 \\
4940\end{array}$ & $\begin{array}{l}2230 \\
1750 \\
3980\end{array}$ & $\begin{array}{l}3240 \\
2200 \\
5440\end{array}$ & - \\
\hline
\end{tabular}

- See footnote to Table 4 . 
vitamin $\mathrm{D}$, this potent source is fatty fish such as herrings, salmon or sardines. If the contribution of vitamin $D$ from this source is deducted, the weekly intake varies much less (Table 6). The highest weekly average of each subject is then between 43 and

Table 6. Average daily intake (i.u.) of vitamin D by the six subjects during 4 weeks

$\begin{array}{lrrrrrr}\text { Source } & \text { I } & 2 & 3 & 4 & 5 & 6 \\ \text { Fish } & 63 & 0 & 74 & 13 & 34 & 111 \\ \text { Margarine } & 15 & 16 & 11 & 9 & 0.5 & 45 \\ \text { Other foods } & 21 & 23 & 27 & 18 & 12 & 27 \\ \text { Total } & 99 & 39 & 112 & 40 & 46.5 & 183\end{array}$

$233 \%$ greater than the lowest, compared with between 233 and $664 \%$ when the vitamin $\mathrm{D}$ from fish is included. The difference between the subjects, from 12 to 72 i.u. daily over the 4 weeks, is now chiefly due to differences in the amount of margarine eaten. Over the 4-weekly period, margarine gave an average daily intake between 45 i.u. (subject no. 6) and 0.5 i.u. (subject no. 5); excluding fish and margarine, the diet supplied between 12 and 27 i.u. daily.

\section{DISCUSSION}

\section{Accuracy of determination of nutrients}

Satisfactory assessment of the nutrients usually consumed by a person depends both on the accuracy of the determination of intakes and on a period of observation necessary to give a representative picture of the dietary pattern. In methods involving the use of food tables, there are two possible sources of error: firstly, errors may occur in the measurement of the amount of foods consumed and, secondly, there may be differences between the actual intake of nutrients and that calculated from food tables. It is possible to imagine that, unless these errors give results that are consistently too high or too low, the two factors of accuracy of method and period of observation might tend to cancel out, and an intake measured over a longer period would not only give a better assessment of the food normally consumed but more accurate values for the nutrients in the foods.

The extent to which the use of food tables gives results different from those of actual analysis has been investigated by several workers. Widdowson \& McCance (r943) concluded that the results obtained by weighing intakes and calculating from food tables were in good agreement with those obtained by analysis for protein, fat, potassium, magnesium and phosphorus, but too low for calcium and iron. Both of the latter are added to the food during cooking, the former from hard water and the latter from the use of iron cooking utensils. Still more calcium can be consumed in the water itself. The results of Widdowson \& McCance would imply that food tables can be legitimately used to assess nutrient intakes, provided it is recognized that the values calculated for calcium and iron are minimal.

More recently, Bransby et al. $(1948 a, b)$ found that weighing the food and calcula- 
tion from food tables gave average values for groups of subjects in quite good agreement with chemical analyses for protein, fat, carbohydrate and calcium, but too low for iron. For individual diets, however, they found appreciable differences between the two methods. These workers studied intakes for a period of 3 days; the fact that the two methods gave better agreement for groups of persons than for individuals indicates that the errors involved in the method of weighing and using food tables tend to cancel out. This supports the suggestion that accuracy is increased for individual intakes when more results are obtained in a more prolonged period of study.

The question then arises as to how much the differences in nutrient intakes revealed in the present study are due to inaccuracies of method. Sources of error in determining food consumption were probably as low as can be achieved. All of the subjects, who weighed their own food, were graduates in science and specializing in dietetics; they were, therefore, not only used to accurate weighing but appreciated the need for this and for accurate recording. Any questions as to method that arose during the survey were answered at once. In addition, since they were able to obtain the detailed recipes for most made-up dishes, it was possible to calculate the nutrients in these more accurately than from tables for 'composite dishes'.

The second source of error, the difference in composition between food consumed and food listed in the tables, could only have been checked by chemical analyses. The results of other workers (quoted above) suggest that the present results, which refer to individual diets, almost certainly do not give an exact record of the quantities of nutrients consumed. It is, moreover, likely that the error is greatest where one nutrient is supplied in large amount by one or two potent sources consumed irregularly, for example vitamin A from liver. Here the variation in composition of different samples of liver is wide and the figure in the food tables is an average value, so that it is quite possible that the amount of vitamin $A$ actually consumed was appreciably different.

These comments are concerned chiefly with the absolute values of nutrients determined from food tables. They would apply less to relative values, for example the comparison of intakes in different weeks by the same or different persons. It is reasonable to assume that the differences (either between subjects or periods) revealed in this study are real within moderate limits. The subjects consumed much of their food in the College, and their diets, over the 4 consecutive weeks studied, were not influenced by seasonal variation in the composition of foods.

In the discussion which follows, therefore, it will be assumed that, whereas the absolute intakes of nutrients may not be exact, the relative intakes as between subjects, and as between different periods for the same subject, are reasonably correct.

\section{Variations in weekly intake}

Calories. One of the interesting features of the intake of calories is the difference in the extent of variation between the subjects. The intake of subject no. 6 was almost constant, whereas that of subject no. 5 in the Ist week was $68 \%$ more than that in the last week. One would like to know whether the degree of variation is the same for any one subject, or whether it changes; in a different study, for example, would it be found 
that subject no. 5 again showed a variation of the same degree, or might she this time have a more constant intake, whereas subject no. 6 varied more?

That there is such a large difference in the intake of calories with some subjects is, of course, most important. It will be recalled that, from studies of a week's intakes in each of 12 months, McHenry et al. (1945) decided that weekly intakes are unrepresentative. In the only subject whose intakes are quoted in their paper, the daily average was $1862 \mathrm{Cal}$. in one week and $2312 \mathrm{Cal}$. (24\% greater) in another. On the other hand, Widdowson \& McCance (1945) and Widdowson (1947, p. 73) concluded that the determination of a week's intake of calories was sufficiently accurate for practical purposes. Yet a closer examination of Boulton's (I945) figures, quoted by Widdowson in support of this conclusion, shows that, of eight children studied for 4 weeks, the calories in the week of highest consumption were from 9 to $34 \%$ more than in the week of lowest consumption. In three of these eight children the difference was at least $28 \%$. It is difficult to reconcile these results with Widdowson's statement that 'a fair estimate of a person's intake (of calories) is obtained from a study lasting for I week'.

The fact that one person's intake of calories may be greater by $50 \%$ or more in one week than in another makes it easier to understand one of the most puzzling results of Widdowson's study of individual children's diets. In each of the age groups she studied, she found one child who had twice as many calories as another. The explanation for this which first comes to mind is a difference in requirements due to a difference in size (and hence in basal metabolism), a difference in activity and a difference in rate of growth. To these must be added possible errors in technique. Although the greatest care was taken to instruct the child or mother in weighing and recording food intakes, it is possible that the accuracy of the measurements was less than, say, the accuracy of the subjects of the present survey. Again, there is the error already discussed derived from the use of food tables. Nevertheless, Widdowson's results were still difficult to understand, for it seemed unlikely that all of these factors could account for one child consuming twice as much food as another of the same age.

Now, however, that we have seen how great can be the variation in one subject from week to week, it is quite possible to explain most, if not all, of this difference. Of the subjects of the present study, subjects nos. I and 3 had much the same average intake of calories over the whole 4 -week period; yet even if they never varied more than they did during this period, subject no. I might easily consume $25 \%$ more calories than subject no. 3 in one week and $30 \%$ fewer calories in another week. Again, subject no. 5, whose average intake of calories in 4 weeks was indeed lower than that of subject no. 4 , might nevertheless in one week have had the same intake and in another week less than half that of subject no. 4. In general, therefore, it seems justifiable to conclude that chance variation alone can account for one person's intake of calories for a week being $50 \%$ or more greater than another person's intake. Such differences, together with differences in requirements and unavoidable errors due to technique, would together go a long way to explain how one child could in a week eat twice as much food as another child of the same age.

Protein, fat and carbohydrate. The weekly variation of these dietary components was 
similar, and one may conclude that, in one week, a person might well consume $50 \%$ more of each of them than in another week. Since there are no recommended allowances for carbohydrate and fat, variation in intake of these components need not be discussed. The situation, however, is different in respect of protein, for which standards of requirements have been laid down. A variation in weekly intake of the order found in these subjects may well mean that a diet studied for only I week might suggest a deficiency of protein in persons who usually consume adequate amounts. This applied, for example, to subject no. 2, whose average daily intake was $5^{6} \mathrm{~g}$. in I week but $65 \mathrm{~g}$. over 4 weeks.

Calcium and iron. The actual amounts of these elements consumed by the subjects are likely, as we have seen, to be higher than the calculated amounts. A moderate increase in calcium will occur because of its presence in water, and an appreciable increase in iron might occur because of its being added to the diet from iron utensils. It is not possible to know how much these additions would affect the amounts consumed or the variation from week to week, but is is likely that the variations would be at least of the same order. With each element, therefore, it is quite possible for one week's record of dietary intake to give a value $50 \%$ more than another week's. Once again this may well mean that a person is judged as having an inadequate supply of an essential nutrient when, over a longer period, the supply is in fact adequate.

Vitamins. Least variation is found with vitamins of the B group, but it is sufficient to lead to error in assessing dietary adequacies. Vitamin $C$ varies more, and a week's intake is certainly not sufficient to give an indication of the usual intake. This is quite apart from the fact that, in Britain, there is an appreciable seasonal variation as the availability of vegetables and fruits changes.

The greatest variation was found with vitamins $A$ and $D$. In both instances, this was due to the consumption, at relatively long and irregular intervals, of exceptionally potent sources of one or the other of these vitamins.

The results for vitamin A make it necessary to reconsider the conclusions drawn in an earlier study (Doraiswami \& Yudkin, 1948). This reported the relationship between dietary vitamin $\mathrm{A}$ and dark adaptation. Dietary intakes were measured as in the present investigation, by postgraduate students weighing their food for I week and calculating nutrients from food tables. It was found that, out of eleven students investigated, only those three whose average daily intake was below 2500 i.u. had a 'vitamin A-labile' dark adaptation. Since it has now been shown that a week's study may give quite unrepresentative values for the intake of vitamin $A$, this pleasing correlation between dietary vitamin A and deficiency-as shown by impaired dark adaptation-must be considered fortuitous.

\section{Relation of intake to recommended allowances}

Calories. The position of calories in relation to recommended allowances is different from that of the nutrients. With the latter, an amount above the minimal requirement is recommended so as to provide a margin of safety; excess is either stored, metabolized or excreted. The intake of calories should exactly match requirement, since excess must lead to increase in weight. Suggested allowances for calories, therefore, even 
more than those for nutrients, are to be considered as average and not as absolute values for every individual.

Some guide as to whether a person's intake of calories matches his requirements is provided by the basal metabolic rate. With persons of similar activity, such as those in this investigation, one would expect that the calories provided by the diets would be to about the same extent above those needed for basal metabolism. The basal metabolism for the six subjects of this study has been calculated from their height and weight (Table 7). Results show that, in four of the subjects, the average intake of

\section{Table 7. Comparison between calculated $24 \mathrm{hr}$. basal metabolism and average} daily caloric intake of the six subjects

$\begin{array}{ccccc}\begin{array}{c}\text { Calculated } \\ \text { basal } \\ \text { metabolism } \\ \text { (Cal.) }\end{array} & \begin{array}{c}\text { Average } \\ \text { daily } \\ \text { intake } \\ \text { (Cal.) }\end{array} & \text { Cal. } & \begin{array}{c}\text { As percentage } \\ \text { of basal } \\ \text { metabolism }\end{array} \\ \text { no. } & 1430 & 2410 & 980 & 69 \\ 1 & 1445 & 2165 & 720 & 50 \\ 2 & 1620 & 2450 & 830 & 51 \\ 3 & 1620 & 2060 & 440 & 27 \\ 4 & 1260 & 1390 & 130 & 7 \\ 5 & 1640 & 2470 & 830 & 51\end{array}$

calories was greater than the calculated basal metabolism by $50 \%$ or more. Although the calculated basal metabolism may have been different from that obtained by direct estimation, the smaller difference in subject no. 4 , and the much smaller difference in subject no. 5, suggest strongly that even the 4 weeks' average intake was, for these two subjects, probably lower than their usual intake. It is especially difficult to imagine how subject no. 5 could continue for long with an intake of energy only a trifle' more than she needed for basal metabolism. It is unfortunate that the subjects were not weighed at the beginning and at the end of the study, for one would have expected subjects nos. 4 and 5 to have lost weight during the survey. The only information available is that subject no. 5 , an Indian girl, lost about ro lb. in weight during the first 6 months of her stay in England. This period began in September 1948 and so included the period of the survey. It might again be mentioned, however, that both subjects nos. 4 and 5 were subjectively well during the period of study.

Nutrients. Although for reasons discussed earlier we cannot accept with complete confidence the absolute figures of intake of nutrients, it is nevertheless worth briefly commenting on the relation between these and the recommended allowances.

I et us assume that the average intake over the 4 weeks is reasonably representative of the usual intake of the subjects (with reservations, as indicated, for subjects nos. 4 and 5). The results show that, apart from subject no. 5 and in one instance subject no. 6 , all the subjects had an intake of protein, iron, vitamins $A, B_{1}$ and $C$, and nicotinic acid approaching or exceeding the B.M.A. standards. The intakes of calcium and riboflavin, however, were below the B.M.A. standards. As regards calcium, the discrepancy was small and was no doubt made up by calcium from water. Since, for many nutrients, the N.R.C. standards are higher than the B.M.A. standards-some- 
times much higher-most of the subjects were moderately or considerably below the N.R.C. standards for calcium, vitamins $B_{1}$ and $C$, riboflavin and nicotinic acid. As the subjects were getting many of their meals at the College, they obtained their full rations in addition. They also had more than the usual knowledge of nutrition and food values, so that it is likely that their diets compared favourably with those of the general population. The fact that, in spite of this, the intakes of most or all of them fell so far short of the N.R.C. recommendations for several nutrients lends support to the opinion already commonly held in this country that these recommendations are unnecessarily high.

We conclude, therefore, that the problem of relating intake to requirement is much more difficult than is usually admitted. We have first the fact that it is not possible to know with any exactitude the requirements for the nutrients of any one person (Yudkin, 1948). It is now also clear that the accurate assessment of a person's representative dietary intake not only involves laborious techniques if serious error is to be avoided, but also a prolonged period of study because of variations in food consumption.

\section{SUMMARY}

I. The diets consumed by six young women have been studied for 4 consecutive weeks and, in two instances, for a further week after a short interval. The diets were weighed by each subject and the calories and nutrients in them calculated from food tables.

2. The weekly intake of calories and nutrients showed considerable variation. The extent of the variation differed with the different dietary components and with the different subjects. For example, in the week of highest intake, one subject took $2 \%$ more calories than in the week of lowest intake, whereas another took $68 \%$ more calories. With vitamin A, the values in the highest week were from two to five times as much as those in the lowest week.

3. It is thus possible for a person to have an intake of any of the dietary components which is apparently adequate in one week and inadequate in another.

4. It is concluded that a dietary survey extending over 7 days cannot be considered to give a sufficiently accurate assessment of the average intake of calories or nutrients by an individual.

I am indebted to Messrs Allen and Hanburys Ltd., The British Drug Houses Ltd., and Messrs H. W. Carter and Co. for grants towards the expenses of this work. My thanks are also due to the subjects of this study for their co-operation, and to Mrs B. Winstanley for aid in the dietary calculations.

\section{REFERENCES}

Accessory Food Factors Committce (1945). War Memor. med. Res. Coun., Lond., no. I4. Boulton, F. N. (1945). Unpublished data (quoted by Widdowson, 1947).

Bransby, E. R., Daubney, C. G. \& King, J. (1948a). Brit. F. Nutrit. 2, 89.

Bransby, E. R., Daubney, C. G. \& King, J. (1948b). Brit. Y. Nutrit. 2, 232.

British Medical Association (1950). Report of the Committee on Nutrition. London: British Medical Association.

Doraiswami, S. \& Yudkin, J. (1948). Brit. med. J. ii, 708. 
Food and Agriculture Organization of the United Nations (1949). Dietary Surveys. Their Technique and Interpretation. Washington: Food and Agriculture Organization of the United Nations.

McHenry, E. W., Ferguson, H. P. \& Gurland, J. (1945). Canad. publ. Hlth F. 36, 355.

McKay, J. \& Patton, M. B. (1935). Bull. Ohio agric. Exp. Sta. no. 549.

National Research Council (1948). Repr. nat. Res. Coun., Wash., no. I29.

Platt, B. S. (1945). Spec. Rep. Ser. med. Res. Coun., Lond., no. 253.

Wait, B. \& Roberts, L. J. (1932). Y. Amer. diet. Ass. 8, 323.

Widdowson, E. M. (1947). Spec. Rep. Ser. med. Res. Coun., Lond., no. 257.

Widdowson, E. M. \& McCance, R. A. (1943). Lancet, 244, 230.

Widdowson, E. M. \& McCance, R. A. (1945). Proc. Nutr. Soc. 3, i 10.

Yudkin, J. (1948). Nutrit. Diet. Catering, 2, 43.

\title{
The Evaluation of Leanness-Fatness in Man: Norms and Interrelationships
}

\author{
BY J. BROŽEK AND A. KEYS \\ Laboratory of Physiological Hygiene, University of Minnesota, \\ Minneapolis, U.S.A. \\ (Received 3 October 1950)
}

One of the fundamental characteristics of man's state of nutrition is the composition of his body. Grossly, at least, this means the proportion of his body-weight accounted for by the basic components of blood (subdivided into plasma and cells), interstitial fluid, bone, fat, and 'active tissues' (principally muscles, glands, and nerves). Body fat shows the most striking variations in states of nutrition varying along the emaciation-obesity continuum. The provision of improved methods for a quantitative estimation of the relative fatness is one of the pressing tasks of nutritional science; it is essential both for the evaluation of calorie nutrition and for the establishment of valid estimates of calorie requirements (cf. Food and Agriculture Organization of the United Nations, 1950).

In the past, the evaluation of fatness has been based almost exclusively on the individual's deviation from some 'standard' reference weight for his sex, age and height. This conforms to popular ideas; a 'fat' person is thought of as a heavy, overweight individual. Clinical monographs on obesity (Rony, r940; Rynearson \& Gastineau, r949) devote little or no space to a quantitative evaluation of the degree of obesity. This is defensible if one is concerned only with very marked deviations from normal where, in the absence of oedema, a large increase in weight is likely to mean simply the accumulation of body fat. Experience with animals generally supports the concept of overweight as 'fatness'. A very heavy pig or goose will not only have a larger total weight than a lean animal of the same breed but, at the same time, a disproportionately large percentage of their body-weight will be accounted for in terms of deposited fat.

In man, variations in physical activity may alter markedly the composition of the body and disturb the relationship between the relative body-weight and fatness so that the relative body-weight (obtained by expressing the actual weight as a percentage 